\title{
Unusual metallic penile foreign body
}

\author{
Kulothungan Gunasekaran, ${ }^{1,2}$ Swetha Murthi ${ }^{3}$
}

${ }^{1}$ Henry Ford Health System, Detroit, Michigan, USA ${ }^{2}$ Department of Internal Medicine, Bassett Healthcare, Cooperstown, New York, USA ${ }^{3}$ Sinai Grace Hospital, Detroit, Michigan, USA

\section{Correspondence to} Dr Kulothungan Gunasekaran, stankuloth@gmail.com

Accepted 12 March 2017

\section{DESCRIPTION}

A man aged 85 years with severe dementia was brought to the emergency room by his wife because of gross haematuria and increasing agitation for a few days. Blood pressure was 89/ $56 \mathrm{~mm} \mathrm{Hg}$, heart rate $96 \mathrm{bpm}$ and oxygen saturation $94 \%$ on room air. His abdomen was mildly distended in the suprapubic area without significant tenderness and a hard mass was palpated on the ventral side of the penile shaft. Laboratory studies showed septicaemia. CT of the abdomen and pelvis revealed a $6 \mathrm{~cm}$ bullet-shaped foreign body within the penile urethra (figures 1 and 2) and trace bilateral hydronephrosis. A 2 inch intact bullet was removed by urology without complications. The patient's wife stated that they had guns and ammunition in the house, but she did not know where he obtained this bullet. The patient was started on broad-spectrum antibiotics and his overall status improved.

Common causes of penile urethral foreign body include auto-erection and psychiatric disorders such as mental retardation and dementia. ${ }^{1}$ Foreign bodies in the penile urethra can be a diagnostic challenge. Most patients feel guilty and delay seeking help, so careful history and physical examination are essential. Symptoms may range from lower abdominal pain, swelling or pain in the body of the penis, haematuria, pyuria or urinary retention. ${ }^{2}$ An ultrasonogram, pelvic $\mathrm{X}$-ray or CT of the abdomen and pelvis can be useful to identify a foreign body's shape and position. ${ }^{3}$ Definitive management includes complete removal of the foreign body with endoscopy, meatotomy, or internal or external urethrotomy. ${ }^{1}$ Owing to the association of psychiatric disease, further evaluation is recommended to help prevent future episodes.

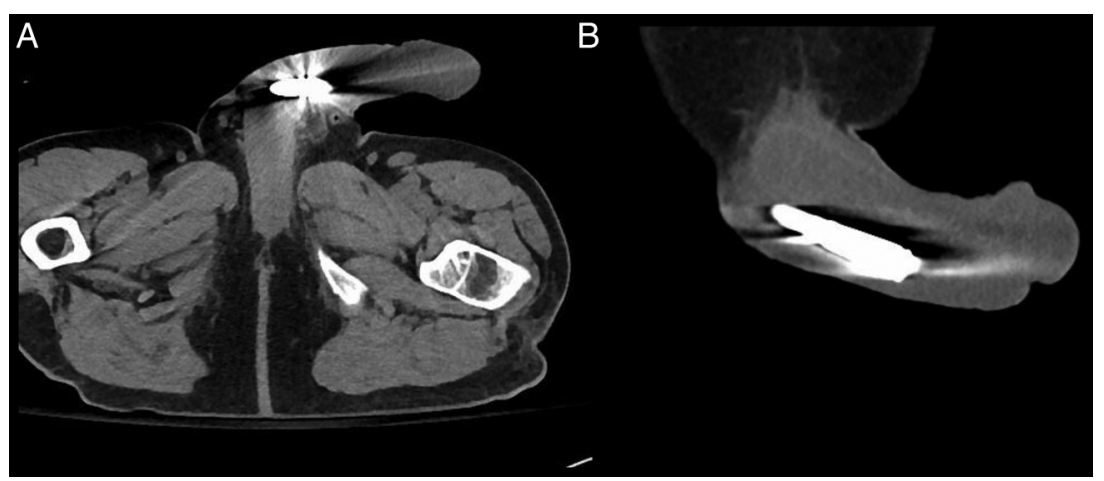

Figure 1 CT scan of the abdomen and pelvis revealing a 2 inch, intact bullet within the penile urethra. (A) Axial view and $(B)$ sagittal view.

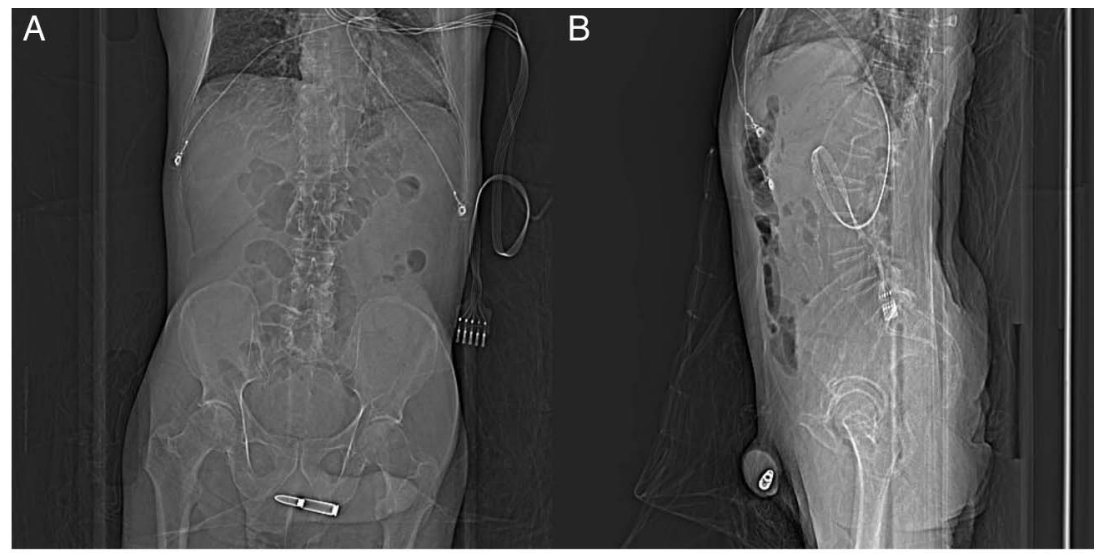

Figure 2 Scout images showing a $6 \mathrm{~cm}$ bullet-shaped foreign body within the penile urethra. (A) Anteroposterior view and (B) lateral view. 


\section{Learning points}

- Foreign bodies should always be considered in the differential diagnosis when patients with dementia or a history of psychiatric disease present with chronic lower urinary tract symptoms.

- Imaging studies like ultrasonogram, pelvic X-ray or CT of the abdomen and pelvis will be useful to identify the foreign body's shape and position.

- Motivation and psychosocial issues should be explored to help prevent future episodes.
Contributors KG is the major contributor in conception, analysis and interpretation of the data involved in this case report. He was involved in draft writing, revision and final approval of the submitted version. SM participated in preparation and review of the manuscript.

Competing interests None declared.

Patient consent Obtained.

Provenance and peer review Not commissioned; externally peer reviewed.

\section{REFERENCES}

1 Bedi N, El-Husseiny T, Buchholz N, et al. 'Putting lead in your pencil': self-insertion of an unusual urethral foreign body for sexual gratification. JRSM Short Rep 2010;1:18.

2 Naidu K, Chung A, Mulcahy M. An unusual urethral foreign body. Int I Surg Case Rep 2013;4:1052-4.

3 Thatte A, Rajendran S, Murphy L, et al. Intravesical foreign body: clinical features and diagnostic clues. BMJ Case Rep 2014;2014:pii:bcr2014204828.

Copyright 2017 BMJ Publishing Group. All rights reserved. For permission to reuse any of this content visit

http://group.bmj.com/group/rights-licensing/permissions.

BMJ Case Report Fellows may re-use this article for personal use and teaching without any further permission.

Become a Fellow of BMJ Case Reports today and you can:

- Submit as many cases as you like

- Enjoy fast sympathetic peer review and rapid publication of accepted articles

- Access all the published articles

- Re-use any of the published material for personal use and teaching without further permission

For information on Institutional Fellowships contact consortiasales@bmjgroup.com

Visit casereports.bmj.com for more articles like this and to become a Fellow 